\title{
Determinants of FDI: Does Democracy Matter?
}

\author{
Hasan Farazmand and Mahvash Moradi \\ Chamran University, Iran
}

\begin{abstract}
Having access to foreign investments allows a country to take advantage of opportunities to which they would otherwise not have access. Many factors interfere with the ability to attract investments in developing countries, but there is lack of consensus on which factors play an unambiguous role. Using different econometric techniques for a data sample of 5 developing countries and the period 1990 to 2012, this study identifies those factors that most explain the determinants of foreign direct investment. Based on results, democracy can positively affect investors' decisions about where to locate capital. The findings also show that foreign direct investment as a share of GDP, is significantly associated with low corruption, inflation, high openness, literacy rate and infrastructure.
\end{abstract}

\section{Keywords}

Foreign Direct Investment, Democracy, Panel Data

\section{Introduction}

The past decades has witnessed a substantial increase in the stock of Foreign Direct Investment (FDI) around the world. In developing countries alone, the stock of FDI increased from about $\$ 10$ billion in 1986 to over $\$ 99$ billion in 1995 (UNCTAD, 1997). However, some of this investment goes to developing democratic countries and some to developing autocratic countries. This phenomenon raises the question among scholars and policymakers: "Does democracy facilitate foreign direct investment?"

To answer this question two perspectives exist about how democracy affects FDI. On the one hand, democratic institutions may have a positive effect on FDI because democracy provides checks and balances on elected officials, and this in turn reduces arbitrary government intervention, lowers the risk of policy reversal and strengthens property right protection (North and Weingast 1989, Li 2009). Olson (1993) stated that established democracies, through executive constraint and judicial independence, guarantee property rights that create a safe, stable and attractive environment for foreign investors to invest. According to Olson, democracy is more attractive to FDI than autocracy. On the other hand, multinational corporations may prefer to invest in autocratic countries because of three reasons. First, democratic constraints over elected politicians tend to weaken the oligopolistic or monopolistic positions. Second, these constraints further prevent host governments from offering generous financial and fiscal incentives to foreign investors. Third, broad access to elected officials and wide political participation offer institutionalized avenues through which indigenous businesses

Copyright (C) 2014 Victoria University. This document has been published as part of the Journal of Business Systems, Governance and Ethics in both online and print formats. Educational and non-profit institutions are granted a non-exclusive licence to utilise this document in whole or in part for personal or classroom use without fee, provided that correct attribution and citation are made and this copyright statement is reproduced. Any other usage is prohibited without the express permission of the publisher. can seek protection. In each case, the increased pluralism ensured by democratic institutions generates policy outcomes that reduce the multinational enterprises degree of freedom in the host developing country (Li and Resnick, 2003). O'Donnell (1978) specified that investors share better with autocrats than with democratic leaders. Whilst both autocrats and democratic leaders may receive economic benefits from FDI, autocrats face lower constraints than 
democratic leaders if they choose to protect foreign investors and investments from pressures such as higher wages, labor protection and unfriendly taxation schemes. According to O'Donnell, autocracy is more attractive to FDI than democracy.

While the economic determinants of FDI flow to developing countries have been analyzed to a considerable degree, the importance of changes in democratic systems in host countries has received relatively little attention. Researchers (Wheeler and Mody (1992), Hines (1995) and Wei (2000)) have studied the correlation between corruption and FDI. Brunetti and Weder (1998) found a negative link between institutional uncertainty and investment. Jun and Singh (1996) inspected the effect of an indicator for political risk on the value of foreign direct investment inflows. However, there is far less literature on the FDI-democracy nexus and what is clear in these papers is that no consensus has been reached about the effect of democracy on FDI. There appears to be three groups in the literature: those that claim a negative effect, those that claim a positive effect, and those that find no effect.

Asiedu and Lien (2011) argued there are only twelve published articles that include democracy as a determinant of FDI. For instance, Resnick (2001) and Li and Resnick (2003) found that the level of democracy has a negative impact on foreign capital flows. However, property rights encourage FDI flows. In contrast, Li and Reuveny (2000) detected FDI has a positive effect on democracy. Also, Rodrik (1996), Harms and Ursprung (2001), Jensen (2003), Busse (2004), Jakobsen (2006), Jakobsen and de Soysa (2006), Adam and Filippaios (2007) and Busse and Hefeker (2007) found that multinational corporations are more likely to be attracted by countries in which democracy is respected. Oneal (1994), Alesina and Dollar (2000) and Büthe and Milner (2008) did not find a significant relationship between democracy and FDI.

As can be seen, few theoretical or empirical papers have studied the effect of democratic systems on FDI. Therefore, the overall effect of democracy on FDI has yet to be determined empirically. This study investigated the determinants of FDI for five developing countries during 1990-2012. The remainder of this paper is organized as follows. Section 2 introduces the literature. Section 3 constructs the model, variables and date. Section 4 supplies empirical procedure and results. Finally, Section 5 concludes and suggests policy recommendation.

\section{Literature review}

Conclusions from a literature review were that the empirical research on FDI and democracy is scant and recent. Although there is considerable empirical literature on the determinants of FDI, few of the studies embody democracy as an explanatory variable. Still fewer empirically investigated the role of democratic systems in absorbing FDI. An exception was Oneal (1994), a pioneer who examined whether foreign firms invest more and collect more profit in authoritarian countries than in democracies. He found that the relationship between regime type and FDI flows is not statistically significant, and that returns on investment are best in developed democracies but greater in authoritarian countries.

Busse (2003) tried to examine empirically the complex relationship between democracy and FDI in a systematic way, using cross-sectional and panel data analysis. The results indicated that, on average, investments by multinationals are significantly higher in democratic countries, thereby refuting the hypothesis that political repression fosters FDI. However, this positive link did not hold for the 1970s. In that period, multinational enterprises were much more likely to invest in countries with repressive regimes, and significantly lower political rights of and civil liberties for the population.

Using both cross-sectional and time-series cross-sectional tests of the determinants of FDI for more than 100 countries, Jensen (2003) concluded that democratic political systems attract higher levels of FDI inflows both across countries and within countries over time. Democratic countries were more appealing attracting as much as 70 percent more FDI than their authoritarian counterparts. 
Busse and Hefeker (2007) explored the linkages among political risk, institutions and foreign direct investment inflows. For a data sample of 83 developing countries covering 1984 to 2003, they identified indicators that matter most for the activities of multinational corporations. The results showed that government stability, internal and external conflict, corruption and ethnic tensions, law and order, democratic accountability of government, and quality of bureaucracy are highly significant determinants of foreign investment inflows.

The issue of whether natural resources in host countries altered the relationship between democracy and foreign direct investment was explored by Asiedu and Lien (2011). They estimated a linear dynamic panel-data model using data from 112 developing countries over the period 1982-2007. Results showed that the effect of democracy on FDI depended on the importance of natural resources in the host country's exports. Democracy facilitates FDI in countries where the share of natural resources in total exports is low, but has a negative effect on FDI in countries where exports are dominated by natural resources.

Nieman and Thies (2012) attempted to sort out the roles that democracy and property rights play in attracting FDI from 1970 to 2008 through careful theorizing and the use of a non-nested hierarchical modeling strategy. Their theoretical and empirical analyses demonstrated that the effect of property rights on attracting FDI is contingent on democratic institutions. That is, in the absence of democratic institutions, property rights protections actually exert a negative impact on FDI. However, as the level of democratic institutionalization improves, the effect of property rights on FDI becomes increasingly positive.

The relationship between foreign direct investment, corruption and democracy was studied by Mathur and Singh (2013). They found that foreign investors care about economic freedoms, rather than political freedoms, in making decisions about where to locate capital. In addition, countries that are more democratic receive less foreign direct investment flows if economic freedoms are not guaranteed. One reason could be that developing economies, becoming democracies, are often unable to push through the kind of economic reforms that investors desire due to the presence of competing political interests.

\section{Model, Variables and data}

FDI is a popular subject in international business literature. Numerous statistical and econometric analyses have identified factors which play a role in explaining FDI. Modeling FDI is a complicated task because so many variables intervene. Among explanatory variables, economic phenomena are quantifiable and available. The selection of the explanatory variables was based on the existing literature and data availability, and then the following equation was chosen:

$\mathrm{FDI}_{\mathrm{i}, \mathrm{t}}=\alpha_{\mathrm{i}}+\gamma_{\mathrm{t}}+\beta_{1} \mathrm{Lit}_{\mathrm{i}, \mathrm{t}}+\beta_{2} \operatorname{InfR}_{\mathrm{i}, \mathrm{t}}+\beta_{3} \mathrm{Opn}_{\mathrm{i}, \mathrm{t}}+\beta_{4} \operatorname{Cor}_{\mathrm{i}, \mathrm{t}}+\beta_{5} \operatorname{Dem}_{\mathrm{i}, \mathrm{t}}+\beta_{6} \operatorname{InfS}_{\mathrm{i}, \mathrm{t}}+\varepsilon_{\mathrm{i}, \mathrm{t}}$

Variables are expressed across a series of countries $(i=1, \ldots, N)$ and time periods $(t=1, \ldots, T)$. The first two terms on the right hand side are the intercept parameters, which change among the various countries $i$ and years $t$. They allow for specific effects across countries $\left(\alpha_{i}\right)$ and through time $\left(\gamma_{t}\right) . \varepsilon_{i t}$ shows random disturbance. FDI net inflows in current US dollars were the dependent variable in the regression,. Explanatory variables are as follow: Lit for literacy rate, InfR for inflation rate, Opn for openness, Cor for corruption, Dem for democracy and InfS for infrastructure.

literacy rate: The first determinants is literacy rate in order to account for the notion that a higher level of education raises the productivity of capital and thus increases a country's attractiveness for foreign investors. Since the literacy rate as a measure of a country's human capital stock exhibits a strong positive correlation with per capita income, this variable also accounts for the fact that richer economies are better locations for market-seeking FDI (Harms and Ursprung, 2001). In a recent paper in 2013, Mathur and Singh used literacy rate and concluded that it has positive and significant effect 
on FDI inflows. We expect the larger the literacy rate, the more absorption of FDI. Based on data scanty we use secondary education as a proxy for literacy rate.

Inflation rate: It is expected that inflation deters foreign investors, since it affects the country's overall financial performance and it relates to macroeconomic mismanagement, which inhibits inward FDI. Asiedu and Lien (2011) inferred that less inflation promote FDI.

Openness: It is measured as the sum of exports and imports divided by gross domestic products and is expected that the greater the trade size the higher the level of FDI inflows. It is likely that economic conditions for a better investment environment may overlap with conditions for a better international trade environment, or simply that trade flows correlate with investment flows $(\mathrm{Ng}, 2010)$.

Corruption: High levels of corruption have been associated with low exposure to international trade, high tariff levels and dependence on natural resources, while corruption itself tends to slow economic growth and discourage investment (Larrain and Tavares, 2004). There is an abundant literature on the effects of corruption on openness, particularly on how higher corruption leads to lower levels of foreign direct investment. Wei (2000) and Smarzynska and Wei (2000) have found evidence that American and European investors are indeed averse to corruption in the host countries. In addition, Mauro (1995) showed evidence that both economic growth and private investment are negatively affected by the extent of corruption.

Democracy: It has been argued that there are many sources that provide ratings on the level of democratization in various countries, but none of the measures of democracy is perfect (Asideu and Lein, 2011). For example, Poe and Tate (1994) stated that the Freedom House data on civil and political liberties, which are one of the most utilized data in the profession, are biased in favor of Christian nations and Western democracies. Casper and Tufis (2003) also cautioned that totally different measures of democracy, even ones extremely correlated, might not be interchangeable. As a result, they will turn out very different results.

Based on literature, three common measures were used to measure democracy. The first measure of democracy is derived from the data on political rights published by Freedom House. The second measure is derived from the democracy index published in Polity IV. The third measure is the measure of democracy published in the International Country Risk Guide. Most of the scant literature on the democracy debate uses Polity Project data (Table 1). Therefore, in order to increase the credibility of results, this study used polity, which is derived from the democracy index published by Polity IV. The Polity IV Project has rated the levels of democracy for each country and year using coded information on the general qualities of political institutions and processes, including executive recruitment, constraints on executive action, and political competition. These ratings were combined into a single, scaled measure of regime governance: the Polity score. The Polity scale ranges from 10 , fully institutionalized autocracy, to +10 , fully institutionalized democracy.

Table 1: Summary of democracy measurements

\begin{tabular}{ll}
\hline Paper & Source for democracy measurement \\
\hline Barrow (1994) & Gastil Index of Political Freedoms \\
\hline Leblang (1996) & Polity II \\
\hline $\begin{array}{l}\text { Jensen (2003) } \\
\text { Li and Resnick (2003) }\end{array}$ & Polity III \\
$\begin{array}{l}\text { Jakobsen and de Soysa } \\
\text { (2006) }\end{array}$ & Polity IV IV and Freedom House \\
$\begin{array}{l}\text { Rana and Kebewar } \\
\text { (2014) }\end{array}$ & Polity IV \\
\hline
\end{tabular}

Source: own investigation

Infrastructure: Foreign investors prefer economies with a well-developed network of roads, airports, water supply, uninterrupted power supply, telephones, and internet access. Poor infrastructures increase the cost of doing business and reduce the rate of return on investment. Other things being 
constant, production costs are typically lower in countries with well-developed infrastructures than in countries with poor infrastructures. Countries with good infrastructures are therefore expected to attract more FDI (Onyeiwu, 2003). Wheeler and Mody (1992) found that infrastructure quality is an important variable for developing countries seeking to attract FDI from the United States. Using a self-reinforcing model of FDI, Cheng and Kwan (2000) found support for good infrastructure (density of roads) as a determinant of FDI into 29 Chinese regions. A measure to capture the level of infrastructure was Internet users per 100 people (people with access to the worldwide network), which was expected to be positively correlated with FDI $^{1}$.

The data used in this paper have been extracted from World Bank and Polity IV for 5 developing countries during 1990-2012. Countries were selected which were successful in attracting FDI, also they should be in the list of democratic countries. Based on the Global Report 2013 of "Center for Systemic Peace" (Figure 1), Malaysia, Philippine, Singapore, Thailand and Turkey were countries with a general trend of rising FDI and democratic systems.

Figure 1: Distribution of governance regimes in the global system

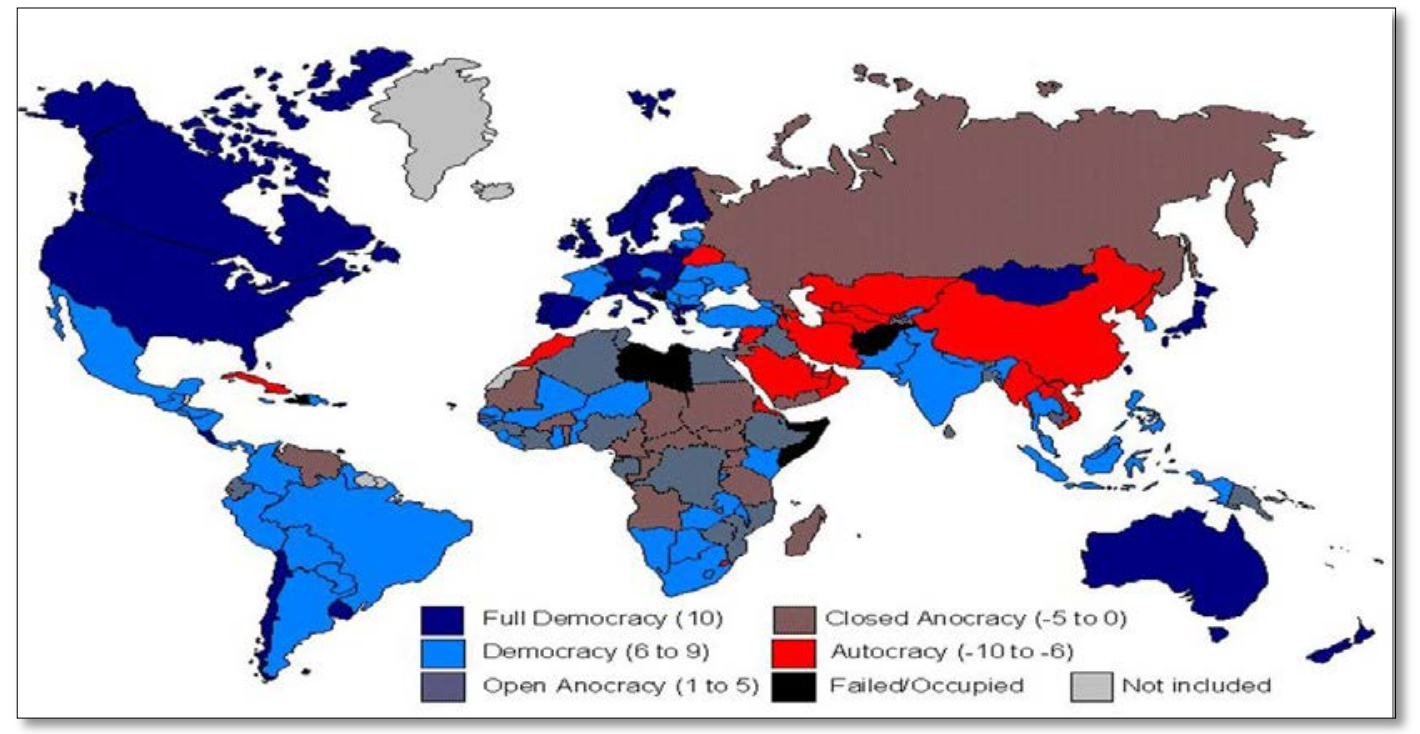

\section{Empirical procedure and results}

The empirical analyses of panel data in this study comprise the following four steps. First, the stationary of data were examined by panel unit root tests. Second, tests for cointegration among panel data were the panel cointegration test developed by Pedroni $(1999,2004)$, and the Hausman test for exploring heteroscedasticity. Fourth, once the panel heteroscedasticity was established, the GLS technique was employed. The procedure of the tests represent in the following manner: Panel unit root test $\rightarrow$ Panel cointegration test $\rightarrow$ Hausman and Likelihood $\rightarrow$ GLS

\section{- Panel unit root test}

There are a variety of panel unit root tests which include Breitung (2000), Hadri (2000), Choi (2001), Levin et al. (2002), Im et al. (2003). The Breitung (2000) and Levin et al. (2002) initiated research on the panel unit root with heterogeneous dynamics, fixed effects, and an individual specific determinant trend. However, they assumed the presence of a homogeneous autoregressive root under the alternative. Whereas Im et al. (2003) allowed the between-group panel unit root tests that permit heterogeneity of the autoregressive root under the alternative. In addition Choi (2001) suggested that comparable unit root tests be performed using the non-parametric Fisher statistic. The null hypotheses of all unit root tests are to have a unit root in a series. While a great deal of research has been devoted

\footnotetext{
${ }^{1}$ See also Mathur and Singh (2013) and Root and Ahmed, 1979
} 
to the use of unit root tests, the most popular seems to be the approaches by Levin et al. (2002) (LLC) and Im et al. (2003) (IPS) unit root tests.

Table 2 reports the results of the LLC and IPS tests. The panel unit root tests provide strong evidence in support of the six series having a unit root and all the variables are integrated of order one ${ }^{2}$. By using these results, we proceed to test for cointegration in order to determine whether there is a need to control for a long-run equilibrium relationship in the econometric specifications.

Table 2: Panel Unit Root Tests

\begin{tabular}{ccc}
\hline Variable & LLC & IPS \\
\hline FDI & -7.748 & -6.485 \\
& $(0.000)$ & $(0.000)$ \\
Lit & -2.081 & -1.445 \\
& $(0.018)$ & $(0.0742)$ \\
InfR & -4.565 & -6.185 \\
& $(0.000)$ & $(0.000)$ \\
Opn & -4.310 & -4.003 \\
& $(0.000)$ & $(0.000)$ \\
Cor & -5.093 & -3.518 \\
& $(0.000)$ & $(0.0002)$ \\
InfS & -4.609 & -4.334 \\
& $(0.000)$ & $(0.000)$ \\
\hline
\end{tabular}

Note * $\mathrm{P}$ values are in parentheses

Source: own estimation

\section{- Panel cointegration test}

The extensive interest in and the availability of panel data has led to an emphasis on extending various statistical tests to panel data. Recent literature has focused on the examination of cointegration in a panel setting. The most used tests are as follow: Pedroni (1999, 2004), Kao (1999), and a Fisher-type test using an underlying Johansen methodology (Maddala and Wu, 1999). Overall, we use Pedroni $(1999,2004)$ panel cointegration test. He proposed two sets of tests. One is based on the within dimension approach which includes four statistics: v-statistic, $\rho$-statistic, PP-statistic and ADFstatistic. These statistics essentially pool the autoregressive coefficients across different countries for the unit root tests on the estimated residuals. These statistics take into account common time factors and heterogeneity across countries. The group tests are based on the between dimension approach which includes three statistics: group $\rho$-statistic, group PP-statistic and group ADF-statistic. These statistics are based on the averages of individual autoregressive coefficients associated with the unit root tests of the residuals for each country in the panel. Table 3 reports both the within and between dimension panel cointegration test statistics. As can be seen from the table, a majority of the statistics significantly reject the null of no cointegration.

Table 3: Results for Pedroni Test

\begin{tabular}{lcll}
\hline Within dimension & & Between dimension & \\
\hline Test statistics & & Test statistics & 4.587 \\
Panel v-statistic & -1.971 & Group $\rho$-statistic & $(1.000)$ \\
& $(0.0001)$ & & -3.619 \\
Panel $\rho$-statistic & 3.839 & Group PP-statistic & $(0.0001)$ \\
& $(0.999)$ & Group ADF-statistic & -3.552 \\
Panel PP-statistic & 2.365 & & $(0.0002)$ \\
& $(0.000)$ & & \\
Panel ADF- & -3.475 & & \\
statistic & $(0.0003)$ & & \\
\hline
\end{tabular}

* $\mathrm{P}$ values are in parentheses

${ }^{2}$ ADF-Fisher and PP-Fisher tests were also performed. All the tests indicated that the respective variables contain a unit root. Results are available upon request from the authors. 


\section{- Hausman}

Panel data may have group effects, time effects, or both. These effects are either fixed effect or random effect. A fixed effect model assumes differences in intercepts across groups or time periods, whereas a random effect model explores differences in error variances. The Hausman specification test compares the fixed versus random under the null hypothesis of the existence of a random effect model (Hausman 1978). The Hausman test specification recommended the use of fixed effect model. Table 4 reports the relevant estimates.

\section{- Panel Heteroscdasitcty}

Before proceeding to the final estimation, test for dynamic heterogeneity across groups are performed. An issue that is of major concern is the heterogeneity of the countries included in the data set. It is well known that the presence of heteroscdasitcty in the disturbances of an otherwise properly specified linear leads to consistent but insufficient parameter estimates. As a result, faulty inferences will be drawn when testing statistical hypotheses in the presence of heteroscdasitcty (White, 1980). The heteroscdasitcty test for the used variables was investigated and results are summarized in Table 4.

Table 4: Results for Hausman and Heteroscdasitcty Tests

\begin{tabular}{llll}
\hline Test & Distribution & Stat & Prob \\
\hline Hausman & Chi2 & 137.02 & 0.000 \\
Heteroscdasitcty & Wald Chi2 & 133.05 & 0.000 \\
\hline
\end{tabular}

Source: own estimation

For avoiding heteroscdasitcty in the model, the Likelihood ratio test was employed. The results indicate that the hypothesis based on the existence of homoscedasticity in variances should be rejected, and that the model has heteroscdasitcty.

\section{- $G L S$}

In statistics, Generalized Least Squares (GLS) is a technique for estimating the unknown parameters in a linear regression model. The GLS is applied when the variances of the observations are unequal (heteroscdasitcty), or when there is a certain degree of correlation between the observations. In these cases, Ordinary Least Squares can be statistically inefficient, or even give misleading inferences. The results of GLS estimation is supplied in Table 5.

Table 5: Results for GLS estimation

\begin{tabular}{cccc}
\hline Variables & Coefficient & $|\mathbf{Z}|$ & Prob \\
\hline Lit & -0.0006 & -10.05 & 0.000 \\
InfR & -0.009 & -9.38 & 0.000 \\
Opn & 1.366 & 3.654 & 0.000 \\
Cor & -2.338 & -1.98 & 0.047 \\
Dem & 1.895 & 2.42 & 0.015 \\
InfS & 0.004 & 4.56 & 0.000 \\
& Prob= & \multicolumn{2}{c}{ Wald $=418.31$} \\
\hline
\end{tabular}

Source: own estimation

All the explanatory variables specified in the econometric function are seen to be significant elements in affecting FDI and the overall fit of the panel model is reasonable. The GLS regression of FDI on various economic and political characteristics of the host country, suggests that the effect of literacy rate on FDI absorption is positive and significant, which is in line with recent empirical evidence by Mathur and Singh (2013). Our statistical analyses provide empirical support for our view about the 
negative effect of inflation on FDI. Prices increment lead to abatement in net profit and property values. In addition, it increases the investment risk and instability in macroeconomic policies.

The estimated results of our panel regression indicate that openness was positively and significantly correlated with investment. The positive impact of openness seems to confirm the arguments that trade liberalization leads to a more general reduction in administrative barriers and improves the business environment in the host economy. Countries with low trade barriers also tend to have low barriers to FDI, as well as convey the right signal to the international business community (Lall, 2000). In a more specific context, free trade zones have been successful in attracting FDI with stable, growing economic environment and trade liberalization (Madani, 1999). Corruption can deter foreign investors from investing in a country. Apart from raising the cost of doing business, corruption slows down the process of obtaining the business permits necessary for operating in the host economy.

The results for democratic systems of government show that foreign investors are also highly sensitive to changes in the framework within which governments operate. Fundamental democratic rights, like civil liberties and political rights do matter to multinationals operating in developing countries. This result is in line with the findings by Harms and Ursprung (2001), Jensen (2003) and Busse (2004), who all showed that basic democratic rights are positively associated with FDI inflows, even if the specifications of their models differ. It has been found that infrastructures that are more extensive were associated with increased FDI.

Government infrastructure is used to refer to a country's political, institutional, and legal environment. It captures aspects of legislation, regulation, and legal systems that condition freedom of transacting, security of property rights, and transparency of government and legal processes (Globerman and Shapiro, 2002).

\section{Conclusion and policy recommendation}

This paper has estimated the effects of democracy on inflows of foreign direct investment. Using data from 1990 to 2012, across 5 developing countries comprised of Malaysia, Philippine, Singapore, Thailand and Turkey. This paper has found and presented evidence that democratic systems increase FDI inflows to developing countries. This finding is largely consistent with findings of previous literature on this topic. We also determine other influential factors like literacy rate, inflation, openness, corruption and infrastructure. All variables show significant sign in explaining FDI.

Over the past decades, developing countries have attempted to improve their business climate in an effort to attract foreign investments. To foster more FDI, many solutions can be suggested, but it is a difficult task because it takes time and it is hard to implement policies that can convince potential investors. To improve the climate for FDI, implementation of a few visible actions is essential in the strategy of attracting FDI. Countries with large domestic markets and proper allocation of resources have inevitably experienced high foreign investments, so strong economic growth and aggressive trade liberalization can fuel the interest of foreign investors. Improving the availability of infrastructure, through higher investment in education and increasing government spending towards capital investment, and phasing out capital controls have been some of the steps taken to boost investor confidence and foreign investment. In addition, a well-designed policy framework and long regime durability could be productive and successful.

\section{Reference}

Adam, A., and Filippaios, F. (2007). Foreign direct investment and civil liberties: A new perspective. European Journal of Political Economy, 23 (4), 1038-1052.

Alesina, A., and Dollar, D. (2000). Who gives foreign aid to whom and why? Journal of Economic Growth, 5 (1), 33-63.

Asiedu, E., and Lien, D. (2011). Democracy, foreign direct investment and natural resource. Journal of International Economics, 84, 99-111. 
Barrow, R. (1994). Democracy and Growth. NBER Working Paper, No. 4909.

Breitung, J. (2000). The local power of some unit root tests for panel data. In: Baltagi, B. (Ed.), Advances in Econometrics, Vol. 15: Nonstationary Panels, Panel Cointegration, and Dynamic Panels. JAI Press, Amsterdam, 161-178.

Brunetti, A., and Beatrice W. (1998). Investment and institutional uncertainty: A comparative study of different uncertainty measures. Weltwirtschaftliches Archiv, 134 (3), 513-533.

Busse, M. (2003). Democracy and FDI. HWWA Discussion Paper 220.

Busse, M. (2004). Transnational corporations and repression of political rights and civil liberties: An empirical analysis. Kyklos, 57 (1), 45-66.

Busse, M., and Hefeker, C. (2007). Political risk, institutions and foreign direct investment. European Journal of Political Economy, 23 (2), 397-415.

Büthe, T., and Milner, H.V. (2008). The politics of foreign direct investment into developing countries: Increasing FDI through international trade agreements? American Journal of Political Science, 52 (4), 741-762.

Casper, G., and Tufis, C. (2003). Correlation versus interchangeability: The limited robustness of empirical finding on democracy using highly correlated data sets. Political Analysis 11, 196203.

Cheng, L.K., and Yum K.K. (2000). What are the determinants of the location of foreign direct investment? The Chinese experience. Journal of International Economics, 51(2), 379-400.

Choi, I. (2001). Unit root tests for panel data. Journal of International Money and Finance, 20 (2), 249-272.

Globerman, S., and Daniel S. (2002). Global foreign direct investment flows: The role of governance infrastructure. World Development, 30, 1899-1919.

Hadri, K., (2000). Testing for stationary in heterogeneous panel data. Econometric Journal, 3, 148161

Harms, P., and Ursprung, H.W. (2001). Do civil and political repression really boost foreign direct investment? Economic Inquiry, 40 (4), 651-663.

Hausman, J. (1978). Specification tests in econometrics. Econometrica, 46 (6), 1251-1271.

Hines, J. (1995). Forbidden payment: Foreign bribery and American business after 1977. NBER Working Paper 5266, Cambridge.

Im, K.S., Pesaran, M.H., and Shin, Y., (2003). Testing for unit roots in heterogeneous panels. Journal of Econometrics, 115, 53-74.

Jakobsen, J. (2006). Does democracy moderate the obsolete bargaining mechanism? An empirical analysis, 1983-2001. Transnational Corporations, 15 (3), 67-106.

Jakobsen, J., and de Soysa, I. (2006). Do foreign investors punish democracy? Theory and empirics, 1948-2001. Kyklos 59 (3).

Jensen, N. (2003). Democratic governance and multinational corporations: Political regimes and inflows of foreign direct investment. International Organization, 57 (3), 587-616.

Jun, K., and Singh, H. (1996). The determinants of foreign direct investment in developing countries. Transnational Corporations, 5 (2), 67-105.

Kao, C. (1999). Spurious regression and residual-based tests for cointegration in panel data. Journal of Econometrics, 90, 1-44.

Lall, S. (2000). FDI and development: Research issues in the emerging context. Oxford: Oxford University.

Larrain, B.F., and Tavares, J. (2004). Does foreign direct investment decrease corruption?. Cuadernos De Economia, 41, 217-230.

Leblang, D. (1996). Property rights, democracy and economic growth. Political Research Quarterly, 49 (1).

Levin, A., Lin, C.F., and Chu, C., (2002). Unit root tests in panel data: Asymptotic and finite sample properties. Journal of Econometrics, 108, 1-24.

Li, Q., and Resnick. A. (2003). Reversal of fortunes: Democratic institutions and foreign direct investment inflows to developing countries. International Organization, 57, 175-211.

Li, Q. (2009). Democracy, autocracy, and expropriation of foreign direct investment. Comparative Political Studies 42 (8), 1098-1127. 
Li, Q., and Reuveny, R. (2000). Economic globalization and democracy: An empirical analysis. Paper presented at the International Studies Association annual meeting, Los Angeles, CA, and the Midwest Political Science Association annual meeting, Chicago.

Madani, D. (1999). A review of the role and impact of export processing zones. Policy Working Paper, No. 2238 (Washington D.C.: World Bank).

Maddala, G.S., and Wu, S. (1999). A comparative study of unit root tests with panel data and a new simple test. Oxford Bulletin of Economics and Statistics 61, 631-652.

Mathur, A., and Singh, K. (2013). Foreign direct investment, corruption and democracy. Applied Economocs, 45, 991-1002.

Mauro, P. (1995). Corruption and growth. Quarterly Journal of Economics ,110 (3), 681-712

$\mathrm{Ng}$, J. (2010). The political economy of democracy and FDI inflows in oil countries. Masters' Thesis for MA, Columbia University in the city of New York.

Nieman, M.D., and Thies, C.G. (2012). Property rights regimes, technological innovation, and foreign direct investment. Under review paper.

North, D.C., and Weingast, B.R. (1989). Constitutions and commitment: The evolution of institutions governing public choice in seventeenth-century England. Journal of Economic History, 49 (4), 803-832.

O'Donnell, G. (1978). Reflections on the patterns of change in the bureaucratic authoritarian state. Latin America Research Review, 13 (1), 3-28.

Olson, M. (1993). Dictatorship, democracy, and development. American Political Science Review, 87 (3), 567-76.

Oneal, J.R. (1994). The affinity of foreign investors for authoritarian regimes. Political Research Quarterly, 47, 565-588.

Onyeiwu, S. (2003). Analysis of FDI flows to developing countries: Is the MENA region different? ERF 10 annual conference, Marrakesh, Morocco, December, 1-22.

Pedroni, P. (1999). Critical values for cointegration tests in heterogeneous panels with multiple regressors. Oxford Bulletin of Economics and Statistics 61, 653-670.

Pedroni, P. (2004). Panel cointegration: Asymptotic and finite sample properties of pooled time series tests with an application to the PPP hypothesis. Econometric Theory, 20, 597-625.

Poe, S., and Tate, N. (1994). Repression of human rights to personal integrity in the 1980s: A global analysis. American Political Science Review, 88 (4), 853-872.

Rana, A.T., and Kebewar, M. (2014). The political economy of FDI flows into developing countries: Does the depth of international trade agreements matter?. MPRA Paper, 53358, University Library of Munich, Germany.

Resnick, A. (2001). Investors, turbulence, and transition: Democratic transition and foreign direct investment in nineteen developing countries. International Interactions, 27 (4), 381-98.

Rodrik, D. (1996). Understanding economic policy reform. Journal of Economic Literature, 34, 9-41.

Root, F., and Ahmed, A. (1979). Empirical determinants of manufacturing direct foreign investment in developing countries, Economic Development and Cultural Change, 27, 751-67.

Smarzynska, B., and Wei, S-J. (2000). Corruption and composition of foreign direct investment: Firm-level evidence, NBER working paper No. 7969.

UNCTAD. (1997). World investment report. Geneva: United Nations Conference on Trade and Development.

Wei, S-J. (2000). How taxing is corruption on international investors?, Review of Economics and Statistics, 82 (1), 1-11.

Wheeler, D., and Mody, A. (1992). International investment location decisions: The case of U.S. firms. Journal of International Economics, 33 (1), 57-76.

White, H. (1980). A heteroskedasticity consistent covariance matrix estimator and a direct test for heteroskedasticity. Econometrica, 48 (4), 817-838. 